\title{
Radionuclides transfer between water and atmosphere in the Loire estuary (FLORE project)
}

\author{
M. Fontugne ${ }^{1}$, D. Maro ${ }^{2}$, L. Tenailleau ${ }^{3}$, G. Abril ${ }^{4}$, M.-V. Commarieu ${ }^{1}$, \\ P. Germain'2, D. Hébert', M. Rozet², C. Voiseux ${ }^{2}$, L. Solier ${ }^{2}$, C. Noury ${ }^{1}$, \\ C. Hatté ${ }^{1}$ and M. Paterne ${ }^{1}$ \\ ${ }^{1}$ Laboratoire des Sciences du Climat et de l'Environnement, UMR 1572-CEA/CNRS, \\ Domaine du CNRS, 91198 Gif-sur-Yvette, France \\ ${ }^{2}$ Institut de Radioprotection et de Sûreté Nucléaire, Laboratoire de Radioécologie \\ de Cherbourg-Octeville, 50130 Cherbourg-Octeville, France \\ ${ }^{3}$ Marine Nationale, Groupe d' Études Atomiques, BP. 34, 50115 Cherbourg Naval, France \\ ${ }^{4}$ Département de Géologie et Océanographie (DGO), Université de Bordeaux 1, CNRS-UMR \\ EPOC 5805, 33405 Talence, France
}

\begin{abstract}
In estuaries, volatiles radionucleides $\left({ }^{14} \mathrm{C},{ }^{3} \mathrm{H},{ }^{131} \mathrm{I}\right)$ originating from anthropogenic liquid waste release from nuclear reactor or hospitals are potentially transferable to the atmosphere. Due to the high biologic activity, the degradation of organic matter produce carbon dioxide fluxes to the atmosphere allowing transfer of ${ }^{14} \mathrm{CO}_{2}$ released by nuclear industry. Similarly tritium is transfered to the atmosphere trough evaporation process. We present here, results obtained during FLORE-1 cruise in February 2003, a winter period when biological activity is supposed to be low. The first results of iodine 131 distribution and estimations of radiocarbon and tritium fluxes are presented.
\end{abstract}

\section{INTRODUCTION}

The behaviour of the toxic substances in the environment covers various fields of investigations like contamination by the radio-elements, heavy metals and organic compounds. The knowledge of the biogeochemical cycles of the radio-elements, basically their temporal and spatial distributions is essential to a better understanding of their biological effects. Estuarine environments present a major interest since they constitute accumulation areas of wastes and rejections of the majority of the anthropogenic activities. These transition zones between fresh waters and ocean, characterised by the change of the physico-chemical properties $(\mathrm{pH}$, salinity, turbidity) allows a redistribution and the recycling of the radio-elements by their speciation or phase change thus modifying their bio-availability. The Loire River estuary receives the rejections of radio-elements coming from various sources like the nuclear thermal power stations (fourteen reactors with discharges of carbon-14, tritium) [1] [2], the hospital complexes (rejections of iodine 131).

The Loire estuary on the French Atlantic coast is $100 \mathrm{~km}$ long with a surface area of $102 \mathrm{~km}^{2}$, and an average depth of 9 metres. The estuary is macrotidal, well mixed and highly turbid. Residence times of waters and suspensions are respectively 2-10 days and 1-2years [3]. The Loire river with an average discharge of $850 \mathrm{~m}^{3} . \mathrm{s}^{-1}$ is highly eutrophic with chlorophyll-a exceeding $100 \mu \mathrm{g} . \mathrm{L}^{-1}$ in summer.

This large biomass in the estuary is submitted to oxidation and microbial activity generating high concentrations of dissolved $\mathrm{CO}_{2}$ and even precipitation of authigenic carbonate [4]. Such a pattern suggests clearly that estuary is a potential source of $\mathrm{CO}_{2}$ to the atmosphere. Recent studies 
around COGEMA La Hague nuclear reprocessing plant show that this area of high bacteriological activity generate high carbon dioxide flux marked by ${ }^{14} \mathrm{CO}_{2}$ originating from liquid waste released of the plant [5] [6]. Similarly in the Bay of Seine evaporating process results in ${ }^{3} \mathrm{H}$ flux from sea to the atmosphere [7]. This indicates that part of volatile radionuclides $\left({ }^{14} \mathrm{C},{ }^{3} \mathrm{H}\right)$ of liquid waste released are recycled in the atmosphere.

The aims of FLORE program are to study the distribution of these volatile radio-elements including ${ }^{131} \mathrm{I}$ and the processes of phase transfer (water-atmosphere) in this estuary especially in the mud plug area where the biochemical activity is intense. We present here, results obtained during FLORE-1 cruise in February 2003, a winter period when biological activity is supposed to be low. The first results of iodine 131 distribution and estimations of radiocarbon and tritium fluxes are presented.

\section{EQUIPMENT AND METHOD}

\subsection{Sampling of seawater and air}

Sampling performed between $15^{\text {th }}$ and $20^{\text {th }}$ February 2003 in the Loire estuary from Saint Nazaire city to Montjean sur Loire upstream of the dynamic tide influence. In the estuary the sampling was performed onboard of the R/V "Côtes de La Manche".

Temperature and salinity of seawater were measured using a SBE 19-03 Seabird equipment and wind direction and speed were recorded. $\mathrm{CO}_{2}$ partial pressure in surface sea water were calculated using $\mathrm{pH}$ and total alkalinity measurements following "Standard Operating Procedures SOP3 and SOP6" of the US Department of Energy [8].

${ }^{14} \mathrm{C}$ and ${ }^{3} \mathrm{H}$ activities in air and water samples were determined using the procedure defined by Maro et al., [5], and Maro et al., [7] respectively. ${ }^{131} \mathrm{I}$ concentration was measured by gamma spectrometry after precipitation of total iodine [9].

\subsection{Fluxes calculations}

\subsection{1 ${ }^{14} \mathrm{C}$ fluxes}

In order to estimate ${ }^{14} \mathrm{CO}_{2}$ fluxes across the sea surface water and the atmosphere interface the partial pressure of carbon dioxide $\left(\mathrm{pCO}_{2}\right)$ were calculated using measurement of total alkalinity and $\mathrm{pH}$ of water. According to Henry's law the difference between $\mathrm{pCO}_{2}$ in air and water indicates if seawater is a source of $\mathrm{CO}_{2}$ to the atmosphere. Carbon dioxide fluxes were calculated following equation (1).

$$
\Phi\left(\mathrm{CO}_{2}\right)\left(\text { mole. } \mathrm{m}^{-2} \cdot \mathrm{s}^{-1}\right)=\mathrm{K} \text {. S. } \Delta \mathrm{pCO}{ }_{2}
$$

$\mathrm{K}\left(\mathrm{m} \cdot \mathrm{s}^{-1}\right)$ is the $\mathrm{CO}_{2}$ transfer coefficient between seawater and atmosphere, $\mathrm{S}$ is solubility of $\mathrm{CO}_{2}\left(\right.$ mole. $\left.\mathrm{m}^{-3} \cdot \mathrm{atm}^{-1}\right)$ and $\Delta \mathrm{pCO}_{2}(\mathrm{~atm})$ is the difference between partial pressure in water and air. $\mathrm{K}$ is a parameter depending on wind speed and has been calculated by using studies of Liss and Merlivat [10], Tans et al., [11] and Wanninkhof and McGillis [12]. As these $\mathrm{K}$ values are slightly different in these three studies we present the three $\mathrm{CO}_{2}$ flux estimates.

The exchange of $\mathrm{CO}_{2}$ between the atmosphere and the surface ocean is an equilibrium process, and the nett $\mathrm{CO}_{2}$ flux is the difference between gas going from water to air and gas going from air to water. Both these fluxes carry ${ }^{14} \mathrm{C}$ at concentrations appropriate to the medium from where they originate, and the nett ${ }^{14} \mathrm{C}$ flux is, once again, the difference. The expression for the nett ${ }^{14} \mathrm{C}$ flux from surface ocean to the atmosphere should be of the form (equation 2).

$$
\Phi\left({ }^{14} \mathrm{C}\right)=\left[{ }^{14} \mathrm{C}\right]_{\mathrm{O}} \Phi_{\mathrm{OA}}\left(\mathrm{CO}_{2}\right)-\left[{ }^{14} \mathrm{C}\right]_{\mathrm{A}} \Phi_{\mathrm{AO}}\left(\mathrm{CO}_{2}\right)
$$

Regarding constant factor due to appropriate units use, ${ }^{14} \mathrm{C}$ fluxes were calculated following equation (3). 


$$
\Phi\left({ }^{14} \mathrm{C}\right)\left(\mathrm{Bq} \cdot \mathrm{km}^{-2} \cdot \mathrm{d}^{-1}\right)=10^{9}\left(\left[{ }^{14} \mathrm{C}\right]_{\mathrm{O}} \cdot \Phi_{\mathrm{OA}}-\left[{ }^{14} \mathrm{C}\right]_{\mathrm{A}} \Phi_{\mathrm{AO}}\right)
$$

where $\left[{ }^{14} \mathrm{C}\right]_{\mathrm{O}}$ and $\left[{ }^{14} \mathrm{C}\right]_{\mathrm{A}}$ are the ${ }^{14} \mathrm{C}$ concentrations $\left(\mathrm{Bq} \cdot \mathrm{Kg}^{-1} \mathrm{C}\right)$ in the surface ocean and air, respectively, and $\Phi_{\mathrm{OA}}$ and $\Phi_{\mathrm{AO}}$ are the $\mathrm{CO}_{2}$ fluxes $\left(\right.$ mole. $\mathrm{m}^{-2} \cdot \mathrm{s}^{-1}$ ) from ocean to air, and air to ocean, respectively.

\section{2. ${ }^{3} \mathrm{H}$ fluxes}

To evaluate the transfer of ${ }^{3} \mathrm{H}$ between water and atmosphere due to discharge into the water by nuclear reactors, the flux of water vapour $\left(\mathrm{L} \cdot \mathrm{m}^{-2} \cdot \mathrm{d}^{-1}\right)$ is calculated first, using Rohwer's formula [13]:

$$
\Phi\left(\mathrm{H}_{2} \mathrm{O}\right)=0.372\left(1-0.000374 \mathrm{P}_{\mathrm{a}}\right)\left(1+0.6 \mathrm{~V}_{\mathrm{w}}\right)\left(\mathrm{e}_{\mathrm{s}}-\mathrm{e}_{\mathrm{a}}\right)
$$

where:

$\Phi\left(\mathrm{H}_{2} \mathrm{O}\right)$ : Flux of water vapour $\left(\mathrm{L} \cdot \mathrm{m}^{-2} \cdot \mathrm{d}^{-1}\right)$,

$\mathrm{P}_{\mathrm{a}}$ : Atmospheric pressure (mbar),

$\mathrm{V}_{\mathrm{w}}$ : Wind speed $\left(\mathrm{m} . \mathrm{s}^{-1}\right)$,

$\mathrm{e}_{\mathrm{s}}$ : Saturated vapour pressure (mbar),

$\mathrm{e}_{\mathrm{a}}$ : Vapour pressure in the atmosphere (mbar).

Then, knowing the concentration of ${ }^{3} \mathrm{H}$ in the water, the flux of ${ }^{3} \mathrm{H}\left(\mathrm{Bq} \cdot \mathrm{m}^{-2} \cdot \mathrm{d}^{-1}\right)$ is determined using equation 5 :

$$
\Phi\left({ }^{3} \mathrm{H}_{2} \mathrm{O}\right)=\Phi\left(\mathrm{H}_{2} \mathrm{O}\right)\left[{ }^{3} \mathrm{Hw}\right]
$$

where:

$\Phi\left({ }^{3} \mathrm{H}_{2} \mathrm{O}\right)$ : Flux of ${ }^{3} \mathrm{H}$ between water and atmosphere $\left(\right.$ Bq. $\left.\mathrm{m}^{-2} \cdot \mathrm{d}^{-1}\right)$, $\left[{ }^{3} \mathrm{Hw}\right]$ : Concentration of ${ }^{3} \mathrm{H}$ in the water $\left(\mathrm{Bq} \cdot \mathrm{L}^{-1}\right)$.

\section{RESULTS AND DISCUSSION}

Results are presented in tables 1,2 and 3 for ${ }^{131} \mathrm{I},{ }^{14} \mathrm{C}$ and ${ }^{3} \mathrm{H}$ respectively.

\subsection{Iodine 131}

${ }^{131}$ I was detected in the fluvial part of the estuary (salinity $0 \mathrm{psu}$ ) between Montjean/Loire and Nantes cities. Activities range between 0.8 and $2 \mathrm{~Bq} \cdot \mathrm{m}^{-3}$.

Table 1. ${ }^{131}$ I concentrations in the fluvial part in Loire estuary.

\begin{tabular}{cccccc}
\hline Station & Date & $\begin{array}{c}\text { Latitude } \\
\mathbf{(}^{\circ}\end{array}$ & $\begin{array}{c}\text { Longitude } \\
\mathbf{(}^{\circ}\end{array}$ & $\begin{array}{c}\text { Salinity } \\
(\mathbf{p s u})\end{array}$ & $\begin{array}{c}{ }^{131} \mathbf{I}\left(\mathbf{B q}^{-\mathbf{m}^{-3}} \mathbf{)}\right. \\
\text { water }\end{array}$ \\
\hline 1 & $02 / 15$ & 47.235 & -0.517 & 0 & 0.8 \\
\hline 8 & $02 / 17$ & 47.176 & -2.016 & 0 & 0.9 \\
\hline 13 & $02 / 18$ & 47.168 & -1.547 & 0 & 1.3 \\
\hline 14 & $02 / 19$ & 47.122 & -1.344 & 0 & 2.0 \\
\hline 16 & $02 / 19$ & 47.178 & -2.018 & 0 & 1.3 \\
\hline
\end{tabular}

No measurement was performed for air samples. As iodine 131 is supposed to be absent in the atmosphere, degassing of this radionucleide and its transfer to the atmosphere is highly probable but has not yet been estimated. 


\subsection{Radiocarbon}

Carbon 14 activities range between 230.8 and 400.9 Bq. $\mathrm{kg}^{-1} \mathrm{C}$ and 230.6 and $255.7 \mathrm{~Bq} \cdot \mathrm{kg}^{-1} \mathrm{C}$ for water and air samples respectively. As the post atmospheric nuclear test activity reference value is around $235 \mathrm{~Bq} \cdot \mathrm{kg}^{-1} \mathrm{C}$ in 2003 , all samples excepted air sample at station 4 and water sample at station 14 are marked by ${ }^{14} \mathrm{C}$ from the nuclear industry. These two samples may have been possibly affected by hard water effect originating from local dissolution of geological carbonate in water sample and a contamination of fossil fuel burning for air during sampling. ${ }^{14} \mathrm{C}$ activity decrease slowly toward the mouth with increasing salinity. The measured $\mathrm{pCO}_{2}$ values vary between 379 to $409 \mu \mathrm{atm}$ (mean value of $391 \mu \mathrm{atm}$ ) and between 384 to $1767 \mu \mathrm{atm}$ (mean value of $874 \mu \mathrm{atm}$ ) for air and water respectively. These indicate that Loire estuary is a source of $\mathrm{CO}_{2}$ for the atmosphere.

$\mathrm{CO}_{2}$ fluxes to the atmosphere are calculated from equation 1 using $\mathrm{K}$ transfer coefficient given in

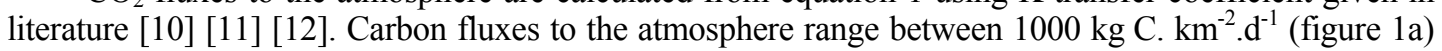
within the mud plug to nothing in oceanic water. For the high $\mathrm{pCO}_{2}$ value in seawater, the difference between the three estimates seems high, nevertheless the relative differences are constant for high and low water $\mathrm{pCO}_{2}$ values. As ${ }^{14} \mathrm{C}$ fluxes given by equation 3 are proportional to the carbon dioxide fluxes, we observe similar difference between ${ }^{14} \mathrm{C}$ fluxes estimates (figure $1 \mathrm{~b}$ ). The highest ${ }^{14} \mathrm{C}$ flux is encountered in the mud plug at low salinity. The ${ }^{14} \mathrm{C}$ fluxes vary between few to $3.110^{5} \mathrm{~Bq} \cdot \mathrm{km}^{-2} \cdot \mathrm{d}^{-1}$.

Table $2 .{ }^{14} \mathrm{C}$ concentrations in the fluvial part in Loire estuary (relative precision is better than $1 \%$ ).

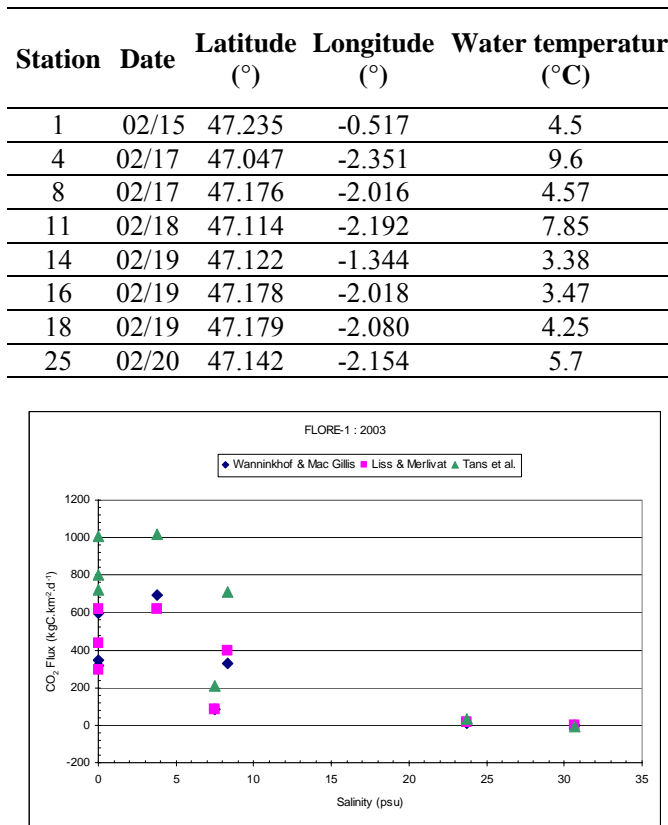

a)

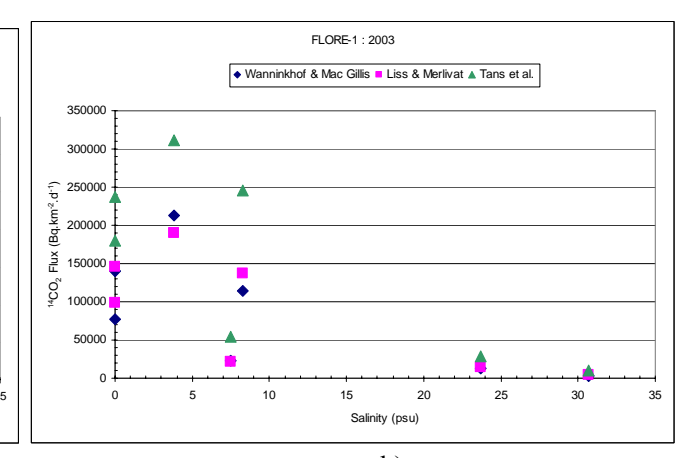

b)

Figure 1. Variations $\mathrm{CO}_{2}$ fluxes (a) and ${ }^{14} \mathrm{C}$ fluxes (b) in surface seawater versus salinity during FLORE 1 cruise.

\subsection{Tritium}

Tritium activities vary from 1.0 to $6.9 \mathrm{~Bq} . \mathrm{L}^{-1}$ and 1.6 to $3.1 \mathrm{~Bq} . \mathrm{L}^{-1}$ for water and air samples, respectively. As the post atmospheric nuclear test activity reference value is less than $1.0 \mathrm{~Bq} . \mathrm{L}^{-1}$ in air and $0,15 \mathrm{~Bq} . \mathrm{L}^{-1}$ in water, all samples are clearly marked by ${ }^{3} \mathrm{H}$ from the nuclear industry [7]. The activities in water decrease linearly with the salinity reflecting the dilution and the mixing of fluvial effluent into marine water. 
Table 3. ${ }^{3} \mathrm{H}$ concentrations in the fluvial part in Loire estuary (relative precision is better than $30 \%$ at $1 \mathrm{~Bq} \cdot \mathrm{L}^{-1}$ ).

\begin{tabular}{|c|c|c|c|c|c|c|c|c|}
\hline Station & Date & $\begin{array}{c}\text { Latitude } \\
\left({ }^{\circ}\right)\end{array}$ & $\begin{array}{l}\text { Longitude } \\
\left({ }^{\circ}\right)\end{array}$ & Water temperature $\left({ }^{\circ} \mathrm{C}\right)$ & $\begin{array}{l}\text { Salinity } \\
\text { (psu) }\end{array}$ & $\begin{array}{c}\text { Wind speed } \\
\left(\mathrm{m} . \mathrm{s}^{-1}\right)\end{array}$ & $\begin{array}{c}{ }^{3} \mathbf{H}\left(\mathbf{B q} \cdot \mathrm{L}^{-1}\right) \\
\text { water }\end{array}$ & $\begin{array}{c}{ }^{3} \mathbf{H}\left(\mathbf{B q} \cdot \mathbf{L}^{-1}\right) \\
\text { air }\end{array}$ \\
\hline 1 & $02 / 15$ & 47.235 & -0.517 & 4.5 & 0 & 4.0 & 6.9 & \\
\hline 2 & $02 / 15$ & 47.219 & -1.008 & 4.7 & 0 & 7.0 & 6.3 & \\
\hline 3 & $02 / 15$ & 47.155 & -1.256 & 4.7 & 0 & 6.0 & 6.9 & \\
\hline 4 & $02 / 17$ & 47.047 & -2.351 & 9.6 & 30.7 & 5.0 & 1.9 & 1.6 \\
\hline 6 & $02 / 17$ & 47.159 & -2.118 & 5.8 & 9.1 & 6.0 & 4.0 & \\
\hline 7 & $02 / 17$ & 47.179 & -2.021 & 4.7 & 2.2 & 6.0 & 5.3 & \\
\hline 8 & $02 / 17$ & 47.176 & -2.016 & 4.6 & 8.3 & 6.0 & 3.4 & 2.9 \\
\hline 10 & $02 / 17$ & 47.105 & -2.199 & 8.1 & 27.9 & 6.0 & 1.0 & \\
\hline 11 & $02 / 17$ & 47.114 & -2.192 & 7.8 & 25.2 & 6.0 & 1.4 & 3.1 \\
\hline 12 & $02 / 17$ & 47.143 & -2.145 & 7.2 & 18.2 & 5.0 & 2.3 & 2.5 \\
\hline
\end{tabular}

The mean water vapour flux calculations obtained during these cruise vary between $2.110^{6} \mathrm{~kg} \cdot \mathrm{km}^{-2} . \mathrm{d}^{-1}$ and $5.810^{6} \mathrm{~kg} \cdot \mathrm{km}^{-2} \cdot \mathrm{d}^{-1}$ (figure 2a). The corresponding variation of the flux of ${ }^{3} \mathrm{H}$ from water to atmosphere range from $3.610^{6} \mathrm{~Bq} \cdot \mathrm{km}^{-2} \cdot \mathrm{d}^{-1}$ to $2.310^{7} \mathrm{~Bq} \cdot \mathrm{km}^{-2} \cdot \mathrm{d}^{-1}$ (figure $2 \mathrm{~b}$ ).

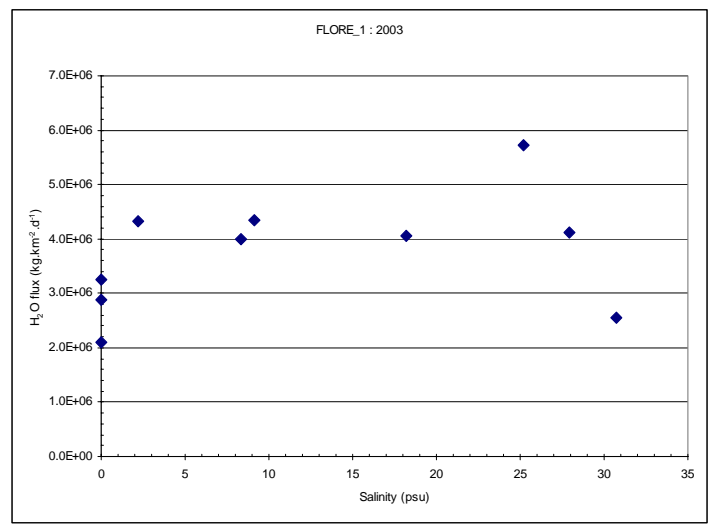

a)

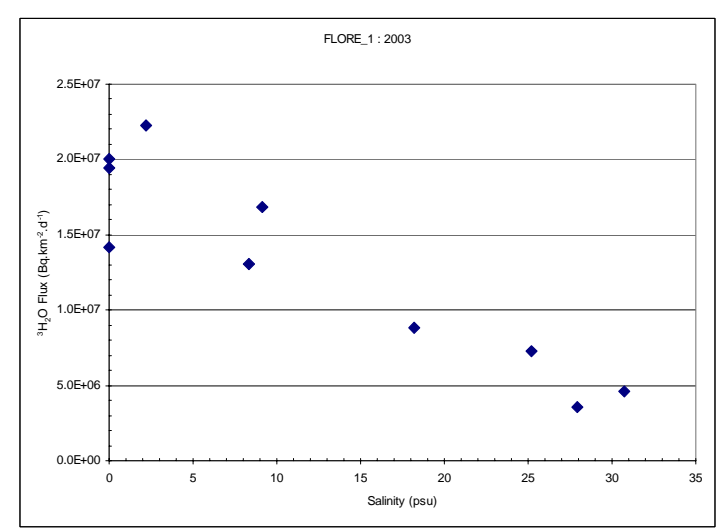

b)

Figure 2. Variations $\mathrm{H}_{2} \mathrm{O}$ fluxes (a) and ${ }^{3} \mathrm{H}$ fluxes (b) in surface seawater versus salinity during FLORE 1 cruise.

\section{CONCLUSIONS}

During FLORE 1 cruise ${ }^{14} \mathrm{C},{ }^{3} \mathrm{H}$ et ${ }^{131} \mathrm{I}$ activities were measured in Loire river estuary. Results indicate clearly a contamination by iodine 131 in the fluvial part of the estuary. Measurements of ${ }^{14} \mathrm{C}$ and ${ }^{3} \mathrm{H}$ activities show the contribution of nuclear industry. Calculation of the radionuclide fluxes show that a significant part of the nuclear waste is transfered to the atmosphere even, if the winter period is characterised by low biological activity and low evaporation in the estuary.

\section{Acknowledgements}

We thank captain Le Bourhis and captain Henri of the "Côtes de La Manche" and their crews. We thank CNRS for logistical support. 


\section{References}

[1] Fontugne M., Sadouni N., Saliot A., Siclet F., Bouloubassi I. and Hatté C., ${ }^{14}$ C activity in dissolved mineral carbon and identified organic matter in Loire estuary (France), Radioprotection 37, C1 (2002), 775-780.

[2] Siclet F., Guesmia M., Ciffroy P., Reyss J.L., Fontugne M., Lepetit G., Jean-Baptiste P. and Drouadaine L., Radionuclides in the Loire river estuary (France): Sources transport and fate, Radioprotection 37, C1 (2002) 761-767.

[3] Relexans J.C., Meybeck M. and Billen G. et al., Algal and microbial processes involved in particulate organic matter dynamics in the Loire estuary, Estuarine Coastal Shelf sci., 27, (1988) 625-644.

[4] Abril G., Commarieu M.V., Maro D., Fontugne M., Guerin F. and Etcheber H., A massive dissolved inorganic carbon released at spring tide in a highly estuary, Geophysical Research Letter, 31, L09346, dio:10.1029/2004g1019714 (2004)

[5] Maro D., Fontugne M., Hatté C., Hébert D. and Rozet M., ${ }^{14} \mathrm{C}$ sources and distribution in the vicinity of La Hague nuclear reprocessing plant: Part II-Marine environment, Radiocarbon 46, $\mathrm{Nr} 2$ (2004), 831-839.

[6] Fontugne M., Maro D., Tenailleau L., Germain P., Hébert D., Rozet M., Noury C., Hatté C., and Paterne M., Carbon 14 transfer from seawater to the atmosphere trough degassing processes in the Bay of Seine (North West of France), Radioprotection, this issue.

[7] Maro D., Tenailleau L., Fontugne M., Germain P., Hébert D. and Rozet M., Tritium transfer between sea and atmosphere in the English Channel (North Cotentin and Bay of Seine), Radioprotection, this issue.

[8] DOE, 1994. Handbook of methods for the analysis of the various parameters of the carbon dioxide system in sea water. Version 2, A. G. Dickson \& C. Goyet (eds). ORNL/CDIAC-74.

[9] Maro D., personale communication.

[10] Liss PS, Merlivat L. 1986. Air-sea exchange rates: introduction and synthesis. In: The Role of Air-Sea exchange in Geochemical Cycling, P. Buat-Ménard (ed.), D. Reidel: 113-27.

[11] Tans PP, Fung IY, Takahashi T.,1990. Observational Constraints on the Global Atmospheric $\mathrm{CO}_{2}$ Budget. Science 247: 1431-38.

[12] Wanninkhof R, McGillis WR. 1999. A cubic relationship between air-sea $\mathrm{CO}_{2}$ exchange and wind speed. Geophys. Res. Letters 26(13): 1889-92.

[13] Rohwer C., Evaporation from a free water surface, U.S. Dept. of Agr., Tech. Bull. (1931). 